Looking backward, looking forward: Mental retardation and the question of equality in the new millennium.

By: J. David Smith

Smith, J. D. (2000). Looking backward, looking forward: Mental retardation and the question of equality in the new millennium. Mental Retardation, 38(5), 457-459.

Made available courtesy of American Association on Intellectual and Developmental Disabilities: http://dx.doi.org/10.1352/0047-6765(2000)038<0457:LBLFMR>2.0.CO;2

*** Reprinted with permission. No further reproduction is authorized without written permission from American Association on Intellectual and Developmental Disabilities. This version of the document is not the version of record. Figures and/or pictures may be missing from this format of the document. $* * *$

\begin{abstract}
:
The writer considers the influence that the growing power of genetic science may bring to bear on people with mental retardation. Within the next century, the eradication of what are thought to be diseases, disorders, and defects may be possible. As a result, it is crucial to decide whether mental retardation is seen as a condition that needs to be prevented in all circumstances or as part of the spectrum of human variation. As genetic intervention techniques abound, there is a danger that people with mental retardation will be further devalued.
\end{abstract}

Keywords: developmental disabilities | genetic science | genetic intervention

\title{
Article:
}

The Pledge of Allegiance was written in 1892 by Francis Bellamy for the quadricentennial celebration of the arrival of Columbus in America. Bellamy wrote the pledge at the request of a committee of state school superintendents under the auspices of the National Education Association. The pledge was intended to become part of a flag-raising ceremony that would bring a new emphasis to the importance of the American flag to school children who were just a generation removed from the Civil War.

Bellamy's original draft of the pledge read as follows: "I pledge allegiance to my Flag and to the Republic for which it stands, one nation, indivisible, with liberty, justice and equality for all." After further consideration, however, Bellamy deleted the word equality. Through his conversations with members of his committee, he had arrived at the conclusion that it would be unacceptable to the state superintendents. He understood that a society that in 1892 still denied the vote and most other civil rights to women and to African American people would not pledge itself to equality (Baer, 1992). 
In the decades that followed, the wording of the Pledge of Allegiance was twice amended. In 1924, the words "my Flag" were changed to "the Flag of the United States of America." In 1954, "under God" was added. With this addition, in a sense, the pledge became both a patriotic oath and a public prayer. It is important to note, however, that more than a century after its adoption, the Pledge of Allegiance is still devoid of a commitment to equality.

\section{LOOKING BACKWARD}

Francis Bellamy's cousin, Edward Bellamy, was a journalist and novelist. He was also a strident voice for social reform during the late 1800s. His most influential work was entitled Looking Backward. This book, originally printed in 1888, was a best-seller in the years following its publication. It was also very influential among American intellectuals at the time. In 1935, the philosopher and educator John Dewey ranked Looking Backward as one of the most important books published in the preceding 50 years (Baer, 1992).

Bellamy's novel is the story of Julian West, who falls into a trance-like sleep in 1887 and is awakened in the year 2000. West awakens to a United States that has no wars, no political parties, and no poverty. Each citizen is an equal shareholder in the social enterprise of the country, and all have equitable and sufficient incomes. Throughout the book Bellamy emphasizes that West finds in the year 2000 a society that is deeply committed to the equality of all of its citizens.

Julian West's guide in the new millennium world to which he has awakened is a physician, Dr. Leete. One of Leete's most profound revelations is that people with disabilities are considered to be equal members of his society. When West expresses surprise that "charity" has become so prevalent in the United States of 2000, an intriguing exchange takes place between the two men.

"Charity!" repeated Dr. Leete. "Did you suppose that we consider the incapable class we are talking of objects of charity?"

"Why naturally," I said, "inasmuch as they are incapable of self-support."

Â $\hat{A}$ Â $̂$ B But here the doctor took me up quickly.

"Who is capable of self-support?" he demanded. "There is no such thing in a civilized society as self-support ... from the moment that men begin to live together, and constitute even the rudest sort of society, self-support becomes impossible. As men grow more civilized ... a complex mutual dependence becomes the universal rule." (p. 178)

Dr. Leete continues his description of the fundamental equality of all people, regardless of individual needs or limitations in independence and productivity, in his society. To this Julian questions, "How can they who produce nothing claim a share of the product as a right?" Dr. Leete answers that each generation in a society inherits most of what it knows and possesses. He asks West: 
How did you come to be possessors of this knowledge and this machinery which represents nine parts to the one contributed by yourself in the value of your product? You inherited it, did you not? And were not these others, these unfortunate and crippled brothers whom you cast out, joint inheritors, co-heirs with you? ... What I do not understand is, setting aside all considerations of justice or brotherly feeling toward the crippled and defective, how the workers of your day could have had any heart for their work, knowing that their children, or grandchildren, if unfortunate, would be deprived of the comforts and even necessities of life. (p. 181)

\section{LOOKING FORWARD}

Remarkable developments in molecular biology and genetic engineering are reported in the popular press almost daily. These advances in scientific knowledge and medical technology will almost certainly change the course of human history. The eradication of what are considered diseases, disorders, and defects may become a reality before the end of the new century. A critical question in this pursuit, however, may be how diseases, disorders, and defects are defined. Is mental retardation, in this context, a disease, a defect, or is it a human difference? Is mental retardation a condition to be prevented in all circumstances or is it part of the spectrum of human variation? Depending upon the answer, what does this say about the status of people with this condition in a democracy? What does it say about their fundamental equality as people?

The danger that people with mental retardation will be further devalued as genetic intervention techniques increase is illustrated by recent remarks by James Watson. Winner of the Nobel Prize and co-discoverer of DNA, Watson was also the first director of the Human Genome Project. In his capacity as leader of the effort to map and sequence the genetic makeup of human beings, Watson also advocated careful consideration of the ethical, legal, and social implications of the project. And yet, in an article entitled "Looking Forward," Watson (1993) dismissed the value of people with severe disabilities when he spoke of the decisions faced by "prospective parents when they learn that their prospective child carries a gene that would block its opportunity for a meaningful life" (p. 314). In the same article he spoke disapprovingly of parents who do not undergo genetic testing. "So we must also face up to the ethical and practical dilemma, facing these individuals who could have undergone genetic diagnosis, but who for one reason or another declined the opportunity and later gave birth to children who must face up to lives of hopeless inequality" (p. 315). More recently Watson spoke to the German Congress of Molecular Medicine and condemned the eugenic philosophy that resulted in the atrocities of the Nazi era. Then, in an amazing contradiction, he advocated what might be termed "parental eugenics." He asserted that the "truly relevant question for most families is whether an obvious good will come from having a child with a major handicap." From this perspective, Watson said, "Seeing the bright side of being handicapped is like praising the virtues of extreme poverty" (cited in Lee, 1998, p. 16).

\section{REVISITING EUGENICS}


In Backdoor to Eugenics, Duster (1990) argued that eugenics is alive and well in our society but in a more subtle manifestation. Although it is still being presented as an economic and social issue, eugenics is also being portrayed as a matter of parental responsibility or irresponsibility. Although less overt, eugenics in its new form may be even more powerful in its impact on the lives of people with mental retardation.

The earlier eugenicists looked to evolutionary theory and Mendelian genetics for moral truths. They believed that natural selection and Mendelian gene distributions could provide models for social ethics. The failure of this approach was evidenced in the needless institutionalization of people deemed to be "unfit" for social "struggle," in the sterilization of people inaccurately assessed to be the carriers of defective genes, and in the moral horrors of the Holocaust. What truths will prevail in the current eugenic climate?

\section{LOOKING FORWARD TO EQUALITY}

Nobel geneticist Simi Linton (1998) has called for a conceptualization of humanity, inclusive of both those with disabilities and those without disabilities, as part of an integrated universe of people. A key to this social formulation is an understanding of the complimentarity, interdependence, and equality of people with differences. Commenting on the work of another Nobel geneticist, Barbara McClintock, Linton wrote, "If something doesn't fit, there's a reason, and you find what it is. Rather than overlook difference, for instance, by naming an exception, an aberration, a contaminant, she worked to understand its place and function" (p. 120).

As the power of genetic science grows, so grows the importance of ethical questions about the implication of that power for human diversity. The greatest challenge for people with mental retardation in this century may be that of having their lives understood within the contexts of the civic values of liberty, justice, and equality. This challenge, and hope, is embodied in the 1892 address that Francis Bellamy delivered during the unveiling of the Pledge of Allegiance. Perhaps borrowing a concept from his cousin Edward, he spoke of looking forward to a new age.

We look forward. We are conscious we are in a period of transition. Ideas in education, in political economy, in social science are undergoing revisions.... The coming century promises to be more than ever the age of the people; an age that shall develop a greater care for the rights of the weak, and make a more solid provision for the development of each individual. (cited in Baer, 1992, p. 41)

Indeed, let us hope that the year 2000 is the beginning of a century that is "more than ever the age of the people," including people with mental retardation.

\section{REFERENCES}

Baer, J. (1992). The pledge of allegiance: A centennial history, 1892-1992. Annapolis, MD: Free State Press. 
Bellamy, E. (1888). Looking backward. New York: Ticknor.

Duster, T. (1990). Backdoor to eugenics. New York: Routledge.

Lee, T. (1998, March/April). "You probably won't like James Watson's ideas about us." Ragged Edge, p.16.

Linton, S. (1988). Claiming disability: Knowledge and identity. New York: New York University Press.

Watson, J. (1993). "Looking forward." Gene, 135, 309-315. 